\title{
APLIKASI PENGENALAN WAJAH MANUSIA PADA CITRA MENGGUNAKAN METODE FISHERFACE
}

\author{
Alwendi $^{1}$, Masriadi ${ }^{2}$ \\ Universitas Graha Nusantara1, Universitas Putra Indonesia "YPTK" Padang 2 \\ J1. Soripada Mulia No 17. Padangsidimpuan, Sumatera Utara, Indonesia \\ e-mail: alwendi60@gmail.com¹, masriadi@upiyptk.ac.id²
}

\begin{abstract}
ABSTRAK
Pengenalan wajah merupakan sebuah sistem identifikasi pribadi yang menggunakan karakteristik wajah seseorang. Pengenalan wajah sendiri merupakan suatu cabang ilmu biometrik, yaitu suatu bidang keilmuan yang menggunakan karakteristik fisik dari seseorang untuk menentukan atau mengungkapkan identitasnya. Objek pengenalan yang digunakan untuk studi pengenalan sudah banyak, salah satunya adalah bentuk wajah. Pada tugas akhir ini dikembangkan suatu sistem pengenalan bentuk wajah pada manusia. Sistem ini dibangun Sistem dibangun dari pengkondisian citra dengan penerapan operator sobel, dan selanjutnya citra terkondisi tersebut dilatih dan diuji. Proses pengenalan bentuk wajah ini dilakukan dengan menggunakan metode Fisherface yang diawali dengan ekstensi file.bmp. Hasil dari penelitian ini adalah membuat sistem pengenalan bentuk wajah manusia dengan empat pengenalan bentuk wajah yaitu Panjang, Persegi, Oval dan Bulat. Sampel akan di latih masing-masing 1 sampel dan di uji masing- masing 8 sampel. Hasil penelitian menunjukkan bahwa keakuratan sistem dengan presentase rata-rata keberhasilan pengenalan bentuk wajah ini berkisar dari $65 \%$, sedangkan persentase rata-rata kesalahan $38 \%$. Tingkat keakuratan pengenalan bentuk wajah dalam penelitian ini sangat ditentukan oleh jumlah pelatihan. Semakin tinggi jumlah pelatihan semakin besar pula presentase hasil dari keakuratan pada sistem ini dalam pengenalan bentuk wajah manusia.
\end{abstract}

Kata kunci: Pengenalan wajah, Bentuk wajah, Fisherface.

\begin{abstract}
Facial recognition is a personal identification system that uses a person's facial characteristics. Facial recognition itself is a branch of biometrics, which is a scientific field that uses the physical characteristics of a person to determine or reveal their identity. There are many recognition objects used for recognition studies, one of which is the face shape. In this final project, a human facial recognition system is developed. This system is built. The system is built from image conditioning with the application of the single operator, and then the conditioned image is trained and tested. The process of recognizing facial shapes is carried out using the Fisherface method, which begins with the file extension.bmp. The result of this research is to create a human face shape recognition system with four facial recognition, namely Long, Square, Oval and Round. Each sample will be trained and tested 8 samples each. The results showed that the accuracy of the system with an average percentage of successful facial recognition was around $65 \%$, while the average error percentage was 38\%. The level of face recognition accuracy in this study is largely determined by the amount of training. The higher the number of training, the greater the percentage of results from the accuracy of this system in recognizing human face shapes.
\end{abstract}

Keywords: Face recognition, Face shape, Fisherface. 


\section{PENDAHULUAN}

Wajah merupakan salah satu ukuran fisiologis yang paling mudah dan sering digunakan untuk membedakan indentitas individu yang satu dengan yang lainnya. Manusia dapat membedakan wajah antara orang yang satu dengan yang lainnya dan mengingat wajah seseorang dengan cepat dan mudah. Oleh karena itu, face recognition merupakan salah satu teknologi biometrics yang banyak dipelajari dan dikembangkan oleh para ahli. Kesulitan dalam pembuatan prosesface recognition terutama adalah karena kekompleksan dari kondisi wajah, yaitu alam hal kualitas gambar yang ditangCatatan: Diskusi untuk makalah ini diterima sebelum tanggal 1 Juni 2007. Diskusi yang layak muat akan diterbitkan pada Jurnal Teknik Elektro volume 7, nomor 1, September 2007. kap, dari segi warna, pencahayaan, hingga posisi gambar yang tertangkap, maupun dalam hal perubahan geometrinya. Oleh karena itu, dalam tulisan ini akan diujikan metode fisherface untuk melakukan pengenalan wajah (Riko arlando S., 2017). Beberapa diantara penelitian yang menggali informasi dari wajah manusia adalah pengenalan wajah. Salah satu penelitian yang berkaitan dengan pengenalan wajah adalah pengklasifikasian yang dapat dikelompokan berdasarkan ras, gender, bentuk dan lainnya. Pendekatan yang paling umum untuk pengenalan wajah didasarkan pada bentuk wajah dan penempatan atribut wajah seperti mata, alis, mata, hidung, bibir dan dagu serta hubungan antara atribut tersebut atau analisis wajah secara keseluruhan yang menghadirkan suatu wajah sebagai suatu kombinasi dari sejumlah wajah kanonik dan dalam penelitian ini akan dibahas klasifikasi bentuk-bentuk wajah.(Rahayu, dkk., 2019).

Metode Fisherface dikembangkan oleh Peter N. Belhumeur, João P. Hespana dan David J. Kreigman pada tahun 1997 untuk mengatasi kelemahan metode Eigenface, khususnya untuk citra dalam variasi pencahayaan dan ekspresi wajah. Objek dariklasifikasi bentuk wajah ini adalah pola wajah dengan empat (4) klasifikasi pola wajah yaitu bentuk wajah panjang, persegi, oval dan bulat. Sampel yang diambil dalam studi kasus ini hanya beberapa bentuk wajah laki- laki.Klasifikasi pola wajah ini hanya terfokus pada wajah bagian depan dan tanpa terhalang objek lain. Sehingga menghasilkan kesimpulan bentuk wajah panjang, persegi, oval dan bulat atau tidaknya wanita tersebut pada proses pengujian melalui sistem. (Agus Harjoko, dkk., 2018)

\section{KAJIAN PUSTAKA}

\subsection{Citra}

Citra adalah suatu representasi (gambaran), kemiripan, atau imitasi dari suatu objek. Citra sebagai keluaran suatu sistem perekaman data dapat bersifat optik berupa foto, bersifat analog berupa sinyal-sinyal video seperti gambar pada monitor televisi, atau bersifat digital yang dapat langsung disimpan pada suatu media penyimpanan. (Kadir Abdul. 2013). Agar dapat diolah dengan menggunakan komputer digital, maka suatu citra harus direpresentasikan secara numerik dengan nilai-nilai diskrit. Proses representasi citra kontinu menjadi nilai-nilai diskrit disebut digitalisasi. Citra digital adalah hasil proses digitalisasi.

Citra ada dua macam, yaitu citra kontinu dan citra diskrit. Citra kontinu dihasilkan dari sistem optik yang menerima sinyal analog, misalnya mata manusia dan kamera analog. Citra diskrit dihasilkan melalui proses digitalisasi terhadap citra kontinu. Beberapa sistem optik dilengkapi dengan fungsi digitalisasi sehingga ia mampu menghasilkan citra diskrit, misalnya kamera digital dan scanner. Citra diskrit disebut juga citra digital. Komputer digital yang umum dipakai saat ini hanya dapat mengolah citra digital. Citra yang akan diolah dalam penelitian ini adalah citra digital.

Suatu citra digital mempunyai fungsi dua dimensi $\mathrm{f}(\mathrm{x}, \mathrm{y})$ yang memiliki ukuran $\mathrm{M}$ baris dan $\mathrm{N}$ kolom dimana $\mathrm{x}$ dan $\mathrm{y}$ adalah koordinat pada bidang dwimatra dan $\mathrm{f}(\mathrm{x}, \mathrm{y})$ adalah intensitas cahaya (brightness) atau amplitudo atau derajat keabuan (grey level). Citra digital merupakan suatu matriks dimana indeks baris dan kolomnya menyatakan suatu titik pada citra tersebut dan elemen matriksnya (yang disebut sebagai elemen gambar atau pixel) menyatakan nilai derajat keabuan pada titik tersebut. Citra digital berukuran $\mathrm{N}$ $\mathrm{x} \mathrm{M}$ (tinggi $=\mathrm{N}$, lebar $=\mathrm{M}$ ) dinyatakan dengan matriks $\mathrm{N}$ x M. Bentuk matriks citra digital dapat dilihat pada gambar 2.1. 


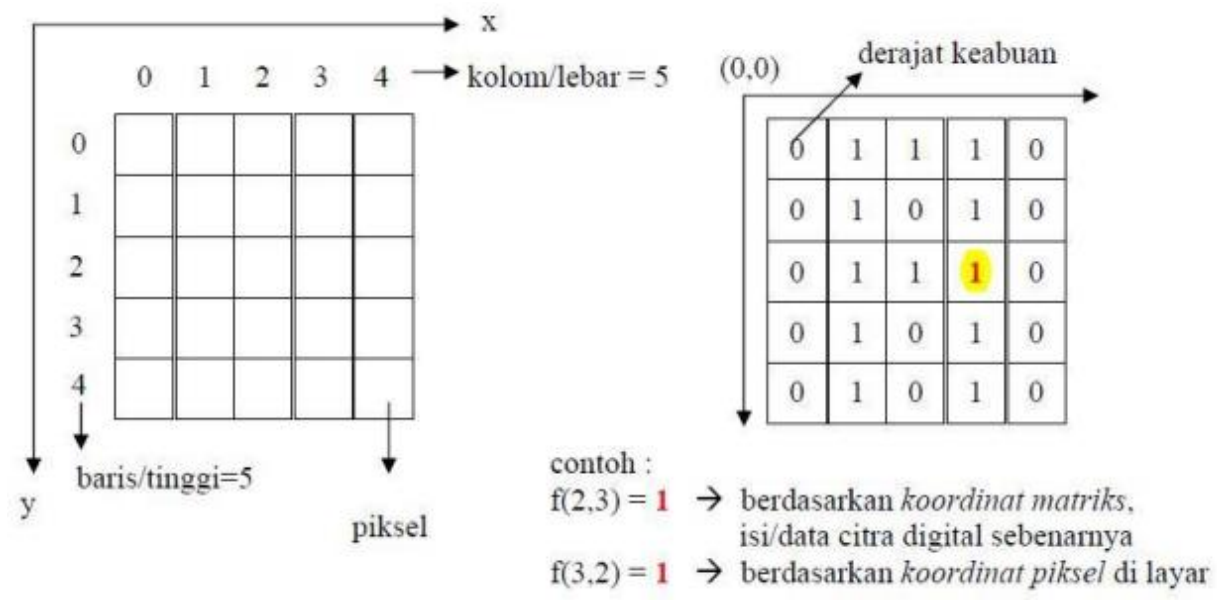

\section{Gambar 1. Representasi Citra Digital 2 Dimensi}

Citra digital pada umumnya berbentuk empat persegi panjang dengan dimensi ukurannya tinggi x lebar. Dimensi citra digital berisi blok-blok kecil yang berupa elemen gambar yang disebut pixel. Pixel-pixel tersebut memuat informasi warna yang menyusun suatu citra. Untuk menunjukkan tingkat pencahayaan pixel, digunakan bilangan bulat yang besarnya 8 bit ( 1 byte) untuk setiap pixelnya, dengan rentang antara 0-255, dimana 0 untuk warna hitam, 255 untuk warna putih, dan tingkat keabuan ditandai dengan nilai antara $0-255$.

\subsection{Metode Fisherface}

Metode Fisherface dikembangkan oleh Peter N. Belhumeur, João P. Hespana dan David J. Kreigman pada tahun 1997 untuk mengatasi kelemahan metode Eigenface, khususnya untuk citra dalam variasi pencahayaan dan ekspresi wajah. Metode ini mentransformasikan vektor dari ruang citra berdimensi-n ke ruang citra berdimensi-m dengan $\mathrm{m}<\mathrm{n} 2$.

Dasar dari metode Fisherface ini adalah Fisher's Linear Discriminant (FLD). FLD ditemukan oleh Robert Fisher pada tahun 1936 untuk klasifikasi taksonomi dan menjadi salah satu teknik yang banyak digunakan dalam pengenalan pola (pattern recognition). FLD merupakan salah satu contoh metode class specific, karena metode ini berusaha untuk membentuk jarak (scatter) antar kelas dan intra kelas sehingga dapat menghasilkan klasifikasi yang lebih baik.

Face recognition atau pengenalan wajah adalah salah satu teknik identifikasi teknologi biometrik dengan menggunakan wajah individu yang bersangkutan sebagai parameter utamanya. Secara garis besar proses pengenalan wajah terdiri dari tiga proses utama (Riko arlando S., 207). yaitu:

1. Deteksi wajah (face detection).

2. Ektraksi ciri/wajah (face/feature extraction).

3. Pengenalan wajah (face recognition).

Secara umum, teknik dan metode dalam pengenalan wajah dapat dikelompokan ke dalam tiga pendekatan berdasarkan data yang dibutuhkannya yaitu:

1. Pendekatan holistik. Pada pendekatan holistik, seluruh bagian atau ciriciri global wajah digunakan sebagai data masukan untuk pengenalan wajah.

Contoh: eigenface, fisherface,nearest feature line (NFL), dan support vector machine (SVM).

2. Pendekatan feature-based. Pada pendekatan feature-based, wajah terbagi berdasarkan ciri-ciri lokal wajah seperti hidung, mulut, mata, dan lainnya yang kemudian digunakan sebagai data masukan.

Contoh : Hidden Markov Model dan Dynamic Link Architecture.

3. Pendekatan hybrid. Pendekatan hybrid menggunakan seluruh bagian wajah dan ciri-ciri lokal wajah sebagai data masukan.

Contoh : modular eigenfacedan hybrid local feature

\subsection{Pengenalan Bentuk Wajah}

Wajah merupakan bagian depan dari kepala yang meliputi: daerah dari dahi hingga dagu, termasuk juga alis, mata, hidung, pipi, mulut, bibir, gigi dan kulit. Wajah digunakan untuk menunjukkan sikap seseorang terhadap ekspresi wajah, penampilan, serta identitas dari seseorang dan tidak ada satu pun wajah yang sama atau serupa mutlak, bahkan pada manusia kembar sekalipun. Wajah sebagai objek dua dimensi 
digambarkan dengan berbagai macam illuminasi, pose dan ekspresi wajah untuk diidentifikasi berdasarkan citra dua dimensi dari wajah tersebut. Oleh sebab itu dengan melihat wajah, manusia dapat mengenali atau mengidentifikasi seseorang dengan mudah. Manusia memiliki bentuk wajah yang berbeda-beda yaitu (Yesicca S, dkk., 2018)

1. Bentuk Wajah Panjang

Wajah panjang (kadang disebut "persegi panjang") ukurannya lebih panjang dari pada lebar wajah. Wajah ini memiliki ukuran yang hampir sama pada pipi, dahi, dan rahang.

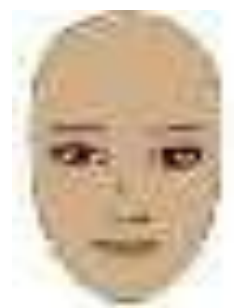

\section{Gambar 2. Bentuk Wajah Panjang}

2. Bentuk Wajah Persegi

Bentuk wajah persegi kira-kira mempunyai panjang dan lebar yang sama, antara pipi dan panjangnya kira-kira berbeda 2,5 sampai $5 \mathrm{~cm}$. Selain itu, ukuran pipi, dahi, dan rahang wajah persegi hampir sama,

sisi wajah atas dan bawah hampir lurus. Rahang wajah persegi pasti mempunyai sudut yang jelas dan tajam pada bagiannya yang terlebar.

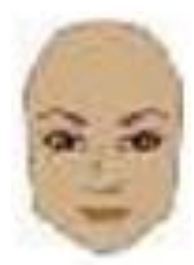

\section{Gambar 3. Bentuk Wajah Persegi}

\section{Bentuk Wajah Oval}

Wajah oval adalah bentuk wajah proporsional mirip dengan bentuk telur terbalik. Lebih panjang dari pada lebarnya, dengan dahi lebih lebar dari pada rahang dan dagu yang halus membulat.

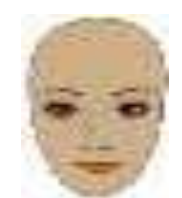

\section{Gambar 4. Bentuk Wajah Oval}

\section{Bentuk Wajah Bulat}

Wajah bulat seperti wajah persegi, kira-kira sama lebar dan panjangnya. Tetapi, wajah ini memiliki dahi yang relatif kecil dan garis rahang kecil yang melengkung. Bila selisih ukuran "pipi" dan "panjang" sekitar 2,5 cm, ukuran dahi lebih kecil dari ukuran pipi, dan rahang hampir tidak mempunyai sudut tajam seperti pada wajah persegi, maka Anda mempunyai wajah bulat.

Aplikasi Pengenalan Wajah Manusia Pada Citra Menggunakan Metode Fisherface (Alwendi, Masriadi) 
ISSN : 2088-589X

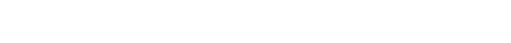

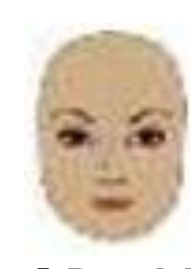

Gambar 5. Bentuk Wajah Bulat

\section{METODE PENELITIAN}

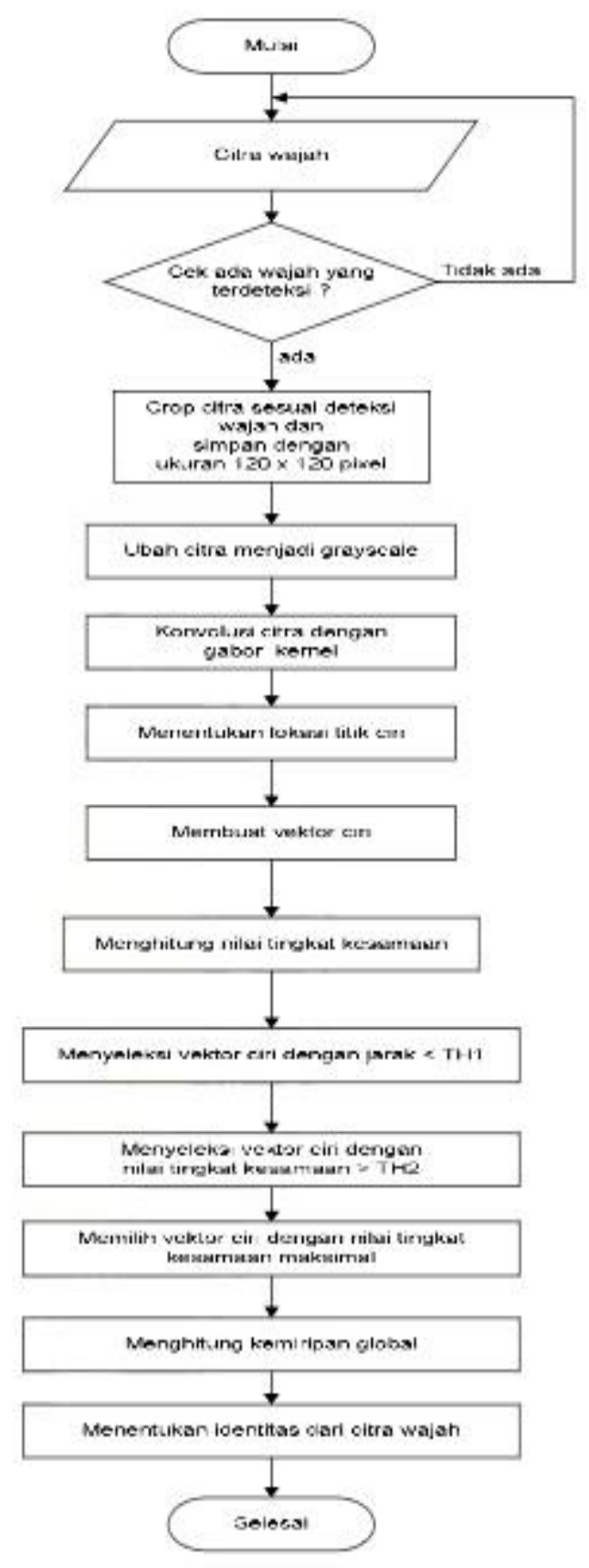

Gambar 6. Metode Penelitian Pengenalan Wajah 


\section{PEMBAHASAN}

Adapun langkah-langkah yang dilakukan dalam penelitian ini adalah sebagai berikut:

1. Pengumpulan Data

Setelah merencanakan penelitian, yang dilakukan terlebih dahulu adalah mengumpulkan referensi tentang Fisherface. Pengolahan Citra serta data yang dibutuhkan dalam pembuatan aplikasi. Data yang digunakan dalam penelitian berupa data yang diambil melalui kamera yang tersedia didalam sistem. Data atau sampel berupa gambar bentuk wajah dari orang-orang yang berbeda- beda.

Tabel 1. Tabel Rincian Sampel Bentuk Wajah

\begin{tabular}{|c|c|c|c|c|}
\hline \multicolumn{5}{|c|}{ Sampel Pelatihan Bentuk Wajah } \\
\hline Panjang & Persegi & Oval & Bulat & Total Sampel \\
\hline & & & \\
\hline
\end{tabular}

2. Skema Sistem

Skema sistem pengenalan pola yang dibangun dalam penelitian ini diilustrasikan pada Gambar 7 .

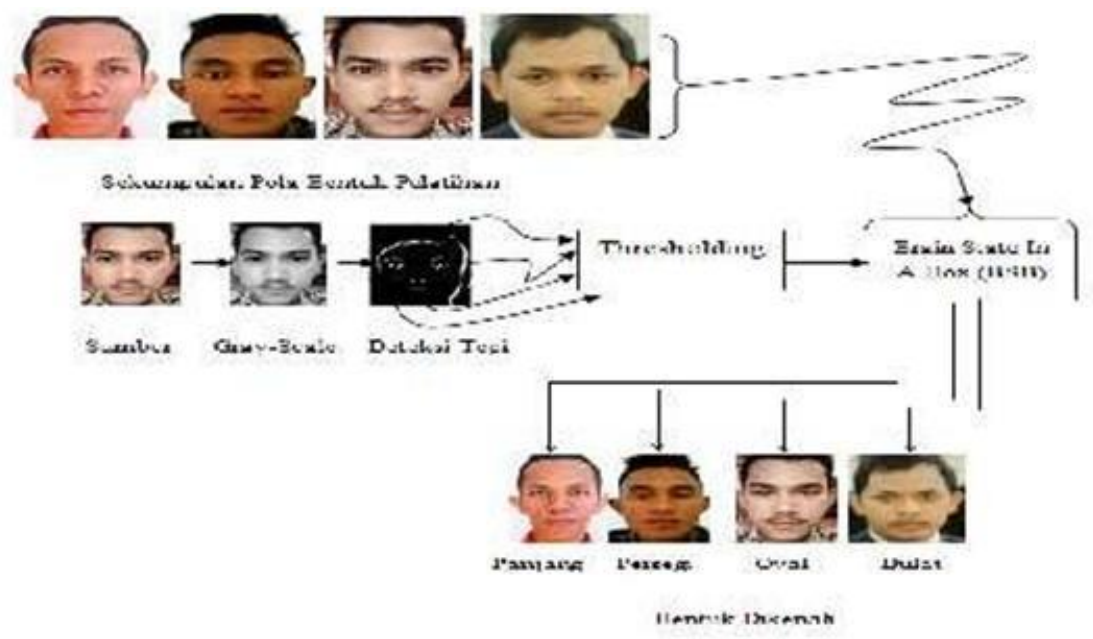

\section{Gambar 7. Skema Sistem Secara Keseluruhan}

Keterangan bentuk wajah hasil pengenalan :

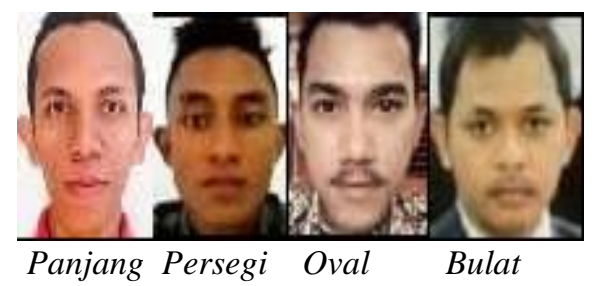

Gambar 8. Wajah Hasil Pengenalan 
Adapun tahapan yang dilakukan setelah sistem menerima input adalah tahapan grey-scale, deteksitepi, thersholding dan uji pengenalan bentuk wajah melalui Fisherface. Pada tahap pre-processing, citra sumber yang menjadi inputan berformat file.bmp. Pada proses utama, komputasi menggunakan Fisherface.

\section{Unjuk Kerja Sistem}

Pengukuran unjuk kerja sistem dilakukan berdasarkan pengukuran seluruh data pengujian berdasarkan spesifikasi atau pengenalan tertentu yang dikolerasikan dengan jumlah data pelatihan yang digunakan. Beberapa hasil pengukuran unjuk kerja sistem terhadap pengujian pada pola mata dipresentasikan sebagai berikut.

Tabel 2. Hasil Unjuk Sistem Bentuk Wajah

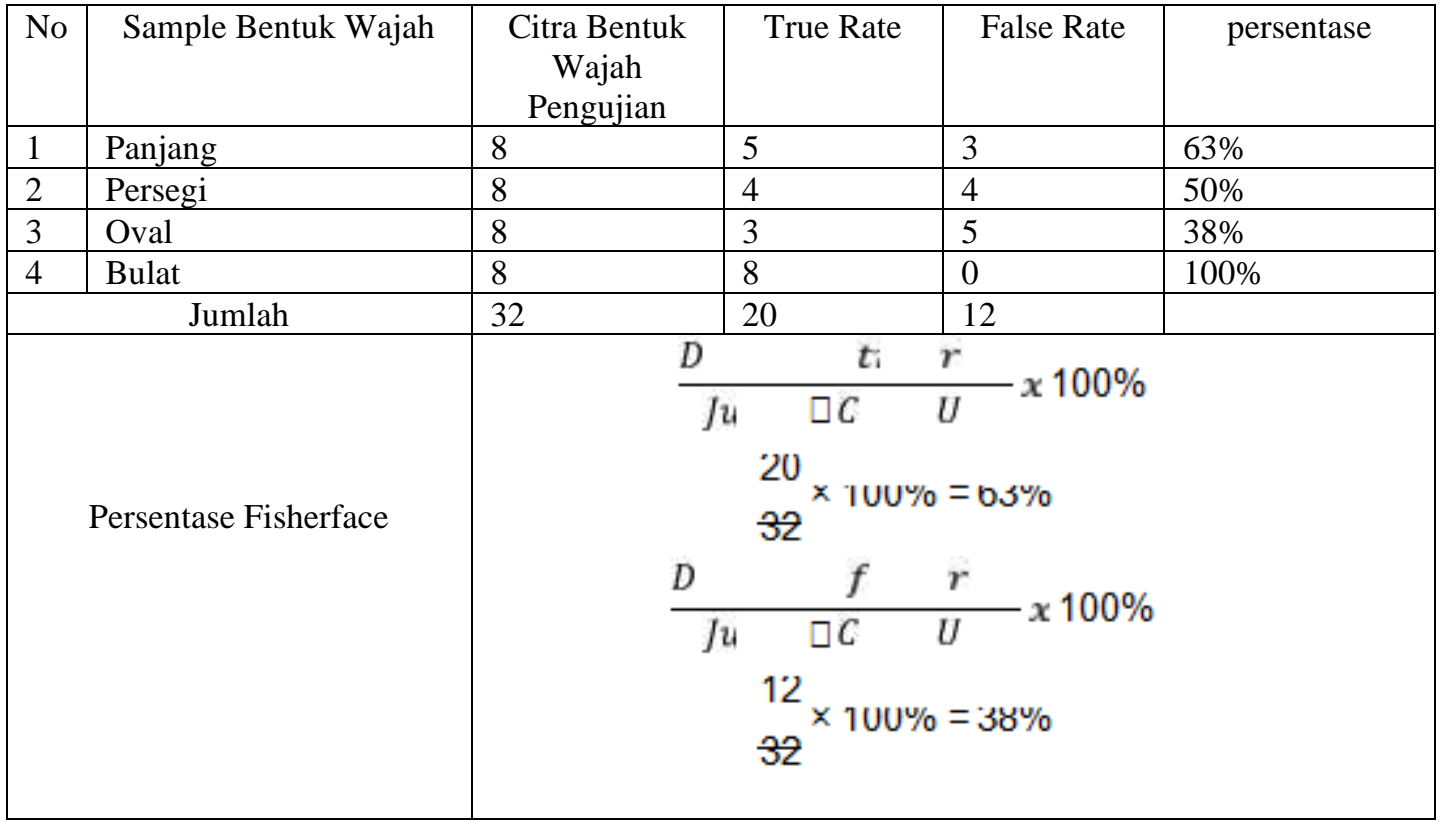

Hasil pengujian menunjukkan bahwa metode Fisherface memiliki detection true rate berkisar $63 \%$ dan detection false rate berkisar $38 \%$. Gambar berikut menunjukkan grafik hasil unjuk kerja sistem.

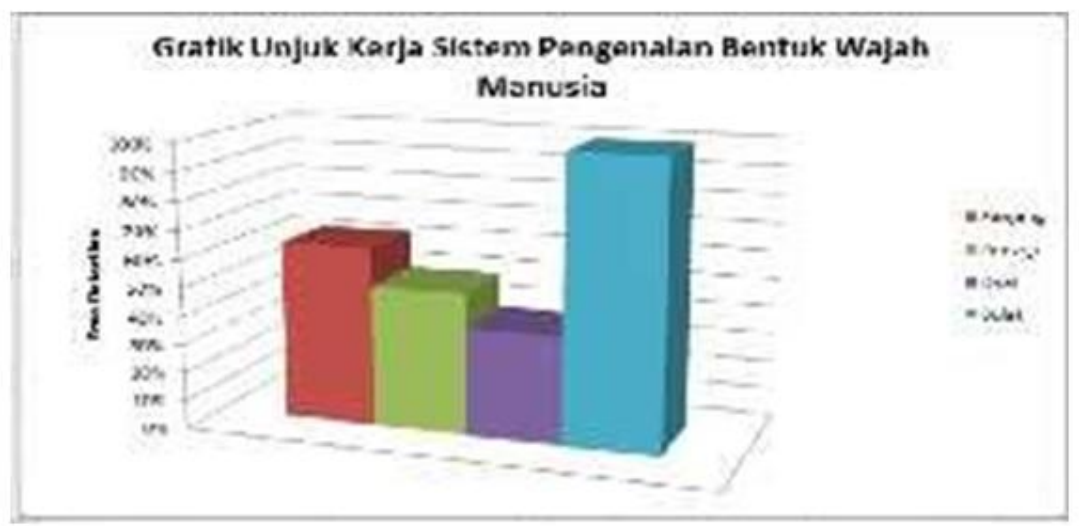

Gambar 9. Grafik Pengenalan Wajah

Berdasarkan grafik diatas maka dapat disimpulkan bahwa sistem tidak mampu mengenal bentuk wajah sepenuhnya, dengan menggunakan metode Fisherface. Hasil Fisherface pengukuran unjuk kerja sistem pengenalan bentuk wajah sebagai berikut:

1. Pada citra wajah yang memuat bentuk panjang, sistem pengenalan memiliki tingkat keakuratan sebesar 63\%. Pada citra wajah yang memuat bentuk persegi, sistem pengenalan memiliki tingkat keakuratan sebesar $50 \%$. 
2. Pada citra wajah yang memuat bentuk oval, sistem pengenalan memiliki tingkat keakuratan paling rendah sebesar $38 \%$.

3. Pada citra wajah yang memuat bentuk bulat, sistem pengenalan memiliki tingkat keakuratan paling tinggi sebesar $100 \%$.

\section{PENUTUP}

\subsection{Kesimpulan}

Setelah menyelesaikan penelitian serta penulisan tugas akhir, berdasarkan uraian-uraian yang telah dijabarkan pada laporan hasil penelitian dan penulisan tugas akhir ini, penulis mengambil kesimpulan sebagai berikut :

1. Keakuratan sistem ini tidak dipengaruhi oleh banyak atau sedikitnya jumlah sampel yang diambil, baik pada saat proses pelatihan serta proses pengujian dilakukan.

2. Tingkat keberhasilan pengujian pada sistem ini tidak hanya didukung oleh peforma sampel bentuk wajah panjang, persegi, oval dan bulat saja, tetapi juga dipengaruhi oleh latar belakang pada saat pengujian dilakukan

3. Hasil penelitian menunjukkan bahwa sistem pengenalan bentuk wajah manusia menggunakan metode Fisherface memiliki detection rate berkisar dari $65 \%$ dan detection false rate $38 \%$.

4. Keunggulan metode Fisherface adalah pada penerapan metode yang lebih sederhana dan kompleks dengan tingkat keakurasian yang tinggi.

\subsection{Saran}

Adapun saran yang dapat di berikan dalam penelitian ini adalah agar nantinya aplikasi pengenalan wajah sudah terintegrasi dengan alat berupa hadware yang terdapat sensor untuk menangkap citra wajah Menggunakan Metode Fisherface.

\section{DAFTAR PUSTAKA}

[1] Agus Harjoko, dan Nyoman tri anindiaputri. 2018 pengenalan wajah berbasis mobile menggunakan fisherface dan distance classifier. Vol 7, No 1 April 2018

[2] Yessica Siagian, Khairil Anwar, Jeperson Hutahaean 2018. Pengenalan wajah pada sistem absensi secara realtime dengan metode wavelet Hal 4

[3] D. Ermawati dan H. Lutfi. 2015. Faktor-Faktor Yang Mempengaruhi Penerapan Sistem Informasi Layanan Akademik Berbasis Web (Studi kasus di IKPIA Perbanas). J. Akunt. dan Audit. 3 (1), 1- 17.

[4] Putra Darma. 2010. Pengolahan Citra Digital. Penerbit Andi. Yogyakarta.

[5] Hermawati, Fajar Astuti. 2013. Pengolahan Citra Digital. Penerbit Andi. Yogyakarta.

[6] Achmad. Dkk. 2013. Pengolahan Citra Digital Menggunakan Delphi. Penerbit Andi. Yogyakarta.

[7] Kurniawan, Dwi ely. 2012. RancangBangun Sistem Pengenalan Wajah Menggunakan Filter Gabor. Program Magister Sistem Informasi. Universitas DiPonogoro, Semarang.

[8] Widiyanto Rebli. 2013. Analisis dan Implementasi Algoritma Fisherface Pada Sistem Pengenalan Wajah Untuk Keamanan Handphone Berbasis Android. Program Sarjana Teknik Informatika. Sekolah Tinggi Manajemen Informatika Dan Komputer AMIKOM Yogyakarta, Yogyakarta.

[9] Tri mulyono. Dkk. 2012. Sistem Pengenalan Wajah Dengan Metode EigenFface Dan Jaringan Syaraf Tiruan (JST). Vol. 15, No. 1, Januari 2012.

[10] Sinurat Sinar. 2014. Analisa Sistem Pengenalan Wajah Berbentuk Citra Digital Dengan Algoritma Principal Components Analysis. Vol. III, No. 1, Mei 2014. 